\title{
On the dissolution, precipitation and transport processes in sulphatic swelling rocks
}

\section{Doctoral Thesis}

\section{Author(s):}

Serafeimidis, Konstantinos

Publication date:

2014

Permanent link:

https://doi.org/10.3929/ethz-a-010138213

Rights / license:

In Copyright - Non-Commercial Use Permitted

Originally published in:

Veröffentlichungen des Instituts für Geotechnik (IGT) der ETH Zürich 244 
DISS. ETH NO. 21707

\section{On the dissolution, precipitation and transport processes in sulphatic swelling rocks}

A dissertation submitted to

ETH Zurich

for the degree of

Doctor of Sciences

presented by

Konstantinos Serafeimidis

Dipl. Civil Engineer

Aristotle University of Thessaloniki

School of Engineering

Department of Civil Engineering

born on 8 June 1981

citizen of the Hellenic Republic

Accepted on the recommendation of

Prof. Dr. Georg Anagnostou, examiner

Prof. Dr. Jan Carmeliet, co-examiner

Prof. Dr. Peter Huggenberger, co-examiner 


\section{Abstract}

Swelling rocks experience a volume increase when interacting with water. In tunnelling, the swelling causes a heave of the tunnel floor, which may impair the serviceability of the structure. If attempts are made to prevent floor heave by means of an invert arch, the so-called swelling pressure develops, which may damage the tunnel lining. Swelling rocks are widely distributed in Switzerland in particular and have caused serious damage to many tunnels. Anhydritic claystones, i.e. rocks consisting of a clay matrix with finely distributed anhydrite, are an especially problematic rock type. The swelling of anhydritic claystones is mainly attributed to the chemical transformation of anhydrite into gypsum.

Considerable knowledge gaps persist with respect to important aspects of the behaviour observed macroscopically (e.g. the effect of counterpressure on heave) and to the microscopic mechanisms underlying swelling behaviour. The knowledge deficit is due to the complexity of the physicochemical processes involved (dissolution of anhydrite and growth of gypsum crystals, seepage flow, ionic diffusion), to the large heterogeneity of natural rock and to the duration of the swelling process, which is very long even under optimum laboratory conditions, making systematic experimental investigation very difficult. Almost all theoretical and experimental investigations reported in the literature focus on the mechanical behaviour of the material. In view of the underlying chemical processes and the potential effects of ionic transport, this is unsatisfactory.

The present dissertation aims to improve our understanding of the mechanisms behind the macroscopic behaviour of swelling in anhydritic claystones. More specifically, the following aspects are investigated: (i) the thermodynamic fundamentals of the anhydrite-water equilibrium and gypsum-water equilibrium; (ii) the kinetics of the chemical reactions involved, i.e. anhydrite dissolution and gypsum precipitation; and (iii) the significance of the transport processes (advection and diffusion). Besides serving as a basis for further research (e.g. through the formulation of comprehensive continuum-mechanical models), the dissertation investigates quantitatively a series of scientifically relevant and interesting questions such as: why is anhydrite rather than gypsum present at shallow depths? why is the swelling pressure in situ and in laboratory tests lower by one order of magnitude than the crystallisation pressure of gypsum? what is the effect on the rate of swelling when anhydrite is sealed by gypsum? is ionic transport really relevant or is it sufficient to consider anhydrite transformation as a relatively simple topochemical process? These topics are explained in the following in more detail.

The dissertation starts by setting out the thermodynamic fundamentals (prerequisites for any continuum-mechanics model explicitly incorporating chemical reactions) of the mechanisms underlying the swelling of anhydritic claystones. In contrast to earlier studies, the equilibrium state in the anhydrite-gypsum-water system is approached by starting from the underlying dissolution and 
precipitation equations. A thermodynamic model is therefore developed first for estimating the individual anhydrite and gypsum solubilities. Although the model is based on well-known thermodynamic principles, it makes the innovative step of considering a range of influencing factors coherently. In addition to the factors commonly considered (temperature, pore water pressure, solid pressure, presence of foreign ions) the model also takes the effect of clay minerals into account, along with solid-liquid interfacial effects. The clay minerals decrease water activity, thus shifting the thermodynamic equilibrium in favour of gypsum. Surface energy effects are significant particularly for the extremely small pores of claystones and they shift the thermodynamic equilibrium in the same direction. The predictions of the model agree well with existing data from the literature.

In tunnels crossing the Gypsum Keuper formation, anhydrite, rather than gypsum, is found at relatively shallow depths of cover. This cannot be explained in simplified thermodynamic terms with reference to the temperature and pressure conditions of the rock at these depths. The fact that anhydrite occurs at shallow depths in Gypsum Keuper has been discussed in the literature, but without finding a quantitatively supported explanation. Understanding why anhydrite, rather than gypsum, occurs at shallow depths is not only interesting from a scientific point of view, but is also indispensable for the formulation of adequate initial conditions in continuum-mechanical models for the swelling of anhydritic claystones. The present dissertation investigates three possible explanatory hypotheses: (i) the rock pores are so small and the solid-liquid interface effects consequently so large that the chemical potential of gypsum is significantly increased; (ii) gypsum growth increases stresses locally to values which are much higher than the overburden pressure and which prevent further growth; and (iii) the pore water has such low activity, due to its interaction with the clay minerals, that anhydrite rather than gypsum represents the thermodynamically stable phase.

In order to investigate the first hypothesis, results are taken from porosimetry experiments (MIP) on samples of Gypsum Keuper. The results show that the rock also contains larger pores where it is thermodynamically possible for gypsum to grow. This means that the entire anhydrite would transform into gypsum as a result of diffusive ionic transport from the smaller pores to the larger pores. This hypothesis therefore has to be abandoned. The validity of the second hypothesis was checked by means of a simplified cavity expansion model and finite element analyses of rock models with randomly distributed pores. The numerical results show that there are always a smaller or larger number of pores around which the developing stresses are lower than the pressure thermodynamically required for anhydrite to be stable. As with the first hypothesis, this would lead to the entire transformation of anhydrite into gypsum, which means that the second hypothesis must also be abandoned. In contrast to these, the low water activity hypothesis is theoretically consistent and does not involve any doubtful assumptions. The third hypothesis therefore seems to be the most convincing one. Although there are theoretical grounds explaining why the activity of the pore water in sulphatic claystones must be low, activity measurements from natural samples are required before a definite statement can be made. 
The present dissertation also investigates why the swelling pressures observed in oedometer tests or in situ are lower by one order of magnitude than the crystallisation pressure of gypsum. In this respect it is essential to draw a clear distinction between three scales: (i) the scale of a gypsum crystal that exerts pressure on the surrounding matrix when its growth is completely constrained (microscale); (ii) the scale of a rock specimen in an oedometer swelling pressure test under volume constraint (macroscale); and (iii) the scale of the rock mass in which swelling is at least partially prevented by a stiff tunnel lining (megascale). The crystallisation pressure of gypsum (microscale) is determined from the abovementioned thermodynamic model as a function of water activity, pore size etc. Subsequently, the thermodynamic model is used in combination with a simplified cavity expansion model and numerical rock models (with stochastic pore distributions) in order to estimate the macroscopic swelling pressure under volume constraint. These relatively simple models can explain why the swelling pressures in laboratory tests are lower by one order of magnitude than the crystallisation pressure of gypsum. Finally, the upper bound of the swelling pressure in the megascale is derived by taking into account the bearing capacity of existing intact linings of tunnels crossing heavily swelling rocks. This upper bound is considerably lower than the crystallisation pressure of gypsum, thus providing additional evidence of the significance of scale.

The swelling of anhydritic claystones is a markedly time-dependent process which may take several decades to complete in nature and is thus important for the design of the final lining. The present dissertation attempts to improve our understanding of the factors governing the time-dependency of swelling by investigating the kinetics of the underlying anhydrite dissolution and gypsum precipitation reactions. (The reaction kinetics are also important for the third part of the thesis, which deals with the interplay between chemical reactions and transport processes in open systems.) A kinetic model is formulated and calibrated by analysing existing experimental results for the individual reactions. In the next step, the model is verified using comparable experimental results from a closed system where anhydrite dissolution and gypsum precipitation take place simultaneously. The model is then used to investigate the effects of a range of parameters (e.g. the initial composition of the rock, the form and size of the rock particles) on the hydration duration. The results indicate that the time period for the transformation of anhydrite into gypsum is governed by the rate of anhydrite dissolution, if the anhydrite is present in the common form of veins with a thickness of $1 \mathrm{~mm}$ or more and there are sufficient nuclei for gypsum precipitation. A further interesting finding is that the hydration time in this dissolution-controlled process does not depend on the initial volume fraction of anhydrite.

In nature, gypsum may frequently seal an anhydrite surface, preventing further hydration. The existing kinetic models for the transformation of anhydrite into gypsum ignore this effect. The present thesis extends the standard kinetic model in order to take sealing into account. The computational results show that - depending on the thickness or size of the anhydrite veins or particles - sealing may be decisive for the evolution of the swelling process and may offer a theoretical explanation for the in situ observations that thick anhydrite layers (in the range of some $\mathrm{cm}$ ) hardly swell at all. 
The third part of the dissertation deals with the significance of advective and diffusive ionic transport. Understanding whether and under what conditions ion transport may be ignored is important both for the design of laboratory tests and for the formulation of manageable continuum-mechanical models (i.e. models that are not unnecessarily overloaded with irrelevant coupled processes). In order to investigate these effects, a coupled model is formulated to take account of the chemical reactions, diffusion and advective ionic transport. Since a chemo-mechanical coupling is not essential for the questions under investigation, a system under volume constraint is considered. The following two questions are analysed quantitatively on the basis of this model: (i) what is the effect of diffusion on oedometer swelling tests? (ii) what is the effect of advective ionic transport in situ?

The motivation for the first question is that ionic diffusion out of the oedometer (towards the distilled water in the container) might influence the test results, because part of the anhydrite would be dissolved and transported away instead of being transformed to gypsum. The idea behind the second question is that advective transport in situ might reduce the calcium and sulphate content in one rock region and increase it in another region. The consequence would be the leaching of anhydrite in the first region and gypsum growth in the second region, even if the latter was initially free of anhydrite. It is therefore evident that transport processes (advection and diffusion) may play a significant role in the swelling process. Computational results show, however, that diffusion is irrelevant in most cases. This is also true with respect to advective transport for the low seepage flow velocities prevailing in the Gypsum Keuper formation. The leaching of anhydrite (and precipitation of gypsum in other locations) can take place only under a combination of high flow velocity (greater than $10^{-5} \mathrm{~m} / \mathrm{s}$, e.g. in fracture zones) and low ion production rate (thick anhydrite veins, low anhydrite content). 


\section{Zusammenfassung}

Quellfähige Gesteinen vergrössern unter Wasseraufnahme ihr Volumen. Im Tunnelbau verursacht das Quellen eine Hebung der Tunnelsohle, welche die Gebrauchstauglichkeit des Bauwerks beeinträchtigen kann. Beim Versuch die Sohlhebung mit einem Sohlgewölbe zu verhindern, entwickelt sich der sogenannte Quelldruck, der dem Tunnelausbau schaden kann. Quellfähige Gesteine sind in der Schweiz besonders weit verbreitet und haben bei einer Reihe von Tunneln erhebliche Schäden verursacht. Eine besonders problematische Gesteinsart sind anhydritführende Tonsteine. Sie bestehen aus einer Tonmatrix mit fein verteiltem Anhydrit. Ihr Quellen ist hauptsächlich auf die chemische Umwandlung von Anhydrit in Gips zurückzuführen.

Es existieren erhebliche Wissenslücken bezüglich wichtiger Aspekte des makroskopisch beobachteten Verhaltens (z.B. die Wirkung eines Gegendruckes auf die Hebung) sowie auch bezüglich der mikroskopischen Mechanismen, die dem Quellverhalten zugrunde liegen. Das mangelnde Wissen ist auf die Komplexität der involvierten physikalischen und chemischen Prozesse (Auflösung von Anhydrit und Wachstum von Gipskristallen, Sickerströmung, Ionendiffusion) und die Dauer des Quellprozesses zurückzuführen. Letztere ist selbst bei kleinen Proben und unter den optimalen Bewässerungsbedingungen von Laborversuchen sehr lang, was in Kombination mit der Heterogenität der Naturgesteine systematische experimentelle Untersuchungen erschwert. Fast alle bestehenden theoretischen und experimentellen Untersuchungen beschränken sich auf das mechanische Materialverhalten, was angesichts der beteiligten chemischen Reaktionen und Transportprozesse unbefriedigend ist.

Die vorliegende Dissertation soll das Verständnis der Mechanismen hinter dem makroskopischen Verhalten von anhydritführenden Tonsteinen verbessern. Insbesondere werden folgende Aspekte untersucht: (i) Die thermodynamischen Grundlagen des Anhydrit-Wasser- und Gips-WasserGleichgewichtes, (ii) die Kinetik der relevanten chemischen Reaktionen, d.h. Auflösung von Anhydrit und Ausfällung von Gips und (iii) die Bedeutung der Transportprozesse (Advektion und Diffusion). Das vertiefte Verständnis dieser Faktoren stellt die Basis für weiterführende Forschungsarbeiten (wie z.B. die Formulierung von umfassenden kontinuumsmechanischen Modellen) und erlaubt die Benatwortung einer Reihe von naturwissenschaftlich relevanten Fragen: Warum ist Anhydrit statt Gips in geringen Tiefen vorhanden? Warum sind die Quelldrücke in situ und in Laborversuchen um eine Grössenordnung tiefer als der Kristallisationsdruck von Gips? Welcher ist der Einfluss der Bildung von Gips auf der Anhydritoberfläche auf die Zeitentwicklung der Hydratation? Ist Ionentransport wirklich relevant oder kann die Anhydritumwandlung als ein relativ einfacher topochemischer Prozess betrachtet werden? Diese Themen werden im Folgenden detailliert erläutert. 
Die Dissertation beginnt mit der Zusammenstellung der thermodynamischen Grundlagen sowie der Mechanismen, die dem Quellen von anhydritführenden Gesteinen zugrunde liegen. Das Verständnis der thermodynamischen Grundlagen ist eine Voraussetzung für jedes kontinuumsmechanische Modell, welches den chemischen Reaktionen explizit Rechnung trägt. Im Gegensatz zu früheren Untersuchungen werden für den Gleichgewichtszustand des Systems Anhydrit-Gips-Wasser die Reaktionen von Auflösung und Ausfällung getrennt berücksichtigt. Deshalb wird ein Modell entwickelt für die Bestimmung der Löslichkeiten von Anhydrit und Gips. Dieses Modell basiert zwar auf bekannten thermodynamischen Prinzipien, ist aber innovativ, weil es eine Reihe von Faktoren theoretisch kohärent erfasst. Ausser den üblicherweise berücksichtigten Faktoren (Temperatur, Porenwasserdruck, Druck auf die Festsubstanzen, Existenz von Fremdionen) werden zusätzlich der Einfluss von Tonmineralien sowie die Oberflächeneffekte erfasst. Die Tonmineralien verringern die Aktivität des Porenwassers und verschieben somit das thermodynamische Gleichgewicht zu Gunsten von Gips. Die Oberflächeneffekte, die im Fall von äusserst kleinen Poren besonders wichtig sind, verschieben das thermodynamische Gleichgewicht ebenfalls zu Gunsten von Gips. Die Vorhersagen des vorgestellten Modells stimmen sehr gut überein mit den bestehenden Daten aus der Literatur.

In Gipskeuper-Tunnel wird in relativ geringen Tiefen Anhydrit statt Gips angetroffen. Dies ist auf dem ersten Blick unerwartet, wenn man die dort herrschenden Temperatur- und Druckbedingungen betrachtet. Das Vorkommen von Anhydrit in geringen Tiefen des Gipskeupers wurde in der Vergangenheit auch von anderen Autoren diskutiert, jedoch nicht quantitativ erklärt. Die Klärung der Frage, warum Anhydrit statt Gips in situ angetroffen wird, ist nicht nur naturwissenschaftlich interessant, sondern auch für die Formulierung adäquater Anfangsbedingungen von kontinuumsmechanischen Modellen für das Quellprozess unerlässlich. In der vorliegenden Dissertation werden drei mögliche Erklärungshypothesen studiert: (i) die Poren sind so klein, dass die Oberflächenspannungen das chemische Potential von Gips im relevanten Mass erhöhen; (ii) das Wachstum der Gipskristalle verursacht eine lokale Erhöhung der Spannungen auf Werte, die viel höher als der Überlagerungsdruck sind und die weitere Hydratation verhindern; (iii) wegen der Wechselwirkungen mit den Tonmineralien ist die Aktivität des Porenwassers so niedrig, dass Anhydrit statt Gips thermodynamisch stabil ist. Um die erste Hypothese zu untersuchen, werden Porosimetrieergebnisse von Gipskeuperproben herangezogen. Sie zeigen, dass es immer auch grössere Poren gibt, in welchen Gips die thermodynamisch stabile Phase darstellt. Das Vorhandensein dieser Poren würde zu einer vollkommener Hydratation von Anhydrit führen, weil die Ionen durch Diffusion von den kleinen Poren zu den grossen Poren migrieren würden. Deshalb muss diese Hypothese aufgegeben werden. Die Gültigkeit der zweiten Hypothese wurde anhand eines vereinfachten Porenexpansionsmodells sowie anhand FEM-Berechnungen überprüft, die Gesteinsmodelle mit stochastisch generierten Porenverteilungen betrachten. Die numerischen Berechnungen zeigen, dass es immer eine kleinere oder grössere Anzahl von Poren gibt, bei 
welchen das Kristallwachstum nur eine bescheidene lokale Spannungserhöhung verursacht. Letztere reicht thermodynamisch bei weitem nicht aus, um das weitere Wachstum zu verhindern. Dies würde (ähnlich wie bei der ersten Hypothese) zur Umwandlung des gesamten Anhydrites in Gips führen. Folglich hält auch die zweite Hypothese einer kritischen Überprüfung nicht stand. Die Hypothese einer ausreichend niedrigen Aktivität des Porenwassers ist hingegen theoretisch konsistent und erfordert keine fragwürdigen Annahmen. Deshalb scheint die dritte Hypothese am überzeugendsten zu sein. Obwohl es theoretische Gründe gibt, warum die Aktivität des Porenwassers der sulfatführenden Tonsteine sehr niedrig sein muss, sind experimentelle Aktivitätsbestimmungen für eine definitive Aussage erforderlich.

Ferner wurde untersucht, warum der Quelldruck in Oedometertests oder in situ um mindestens eine Grössenordnung niedriger ist als der Kristallisationsdruck von Gips. In dieser Hinblick ist es erforderlich, zwischen drei Massstäben sauber zu unterscheiden: (i) dem Massstab eines Gipskristalls, der einen Druck gegen die umgebende Gesteinsmatrix ausübt, wenn sein Wachstum vollkommen eingeschränkt wird (Mikroskala); (ii) dem Massstab einer Gesteinsprobe im Oedometer, derer Quelldehnung vollkommen verhindert wird (Makroskala); und (iii) dem Massstab des Gebirges, dessen Quellung durch ein steifes Tunnelgewölbe mindestens teilweise verhindert wird (Megaskala). Der Kristallisationsdruck von Gips (Mikroskala) wurde auf der Grundlage des entwickelten thermodynamischen Modells in Funktion der verschiedenen Faktoren (Porengrösse, Wasseraktivität usw.) bestimmt. Anschliessend wurde das thermodynamische Modell mit einem vereinfachten Porenexpansionsmodell sowie mit numerischen Gesteinsmodellen mit stochastisch generierten Porenanordnungen kombiniert, um den makroskopischen Quelldruck unter vollkommener Volumenkonstanz abzuschätzen. Diese relativ einfachen Modelle vermögen zu erklären, weshalb die Quelldrücke im Labor eine Grössenordnung niedriger sind als der Kristallisationsdruck von Gips. Schliesslich wurde eine Höchstgrenze des Quelldruckes in der Megaskala abgeschätzt, indem man die Tragfähigkeit vorhandener intakter Ausbauten von Tunnels, die stark quellfähigen Gesteine durchqueren, betrachtet hat. Diese Untersuchungen haben auch gezeigt, dass die in situ Quelldrücke bei weitem niedriger sind als der Kristallisationsdruck von Gips.

Das Quellen von anhydritführenden Tonsteinen ist ein ausgeprägt zeitabhängiger Prozess, der in der Natur mehrere Jahrzehnte dauern kann und deshalb für Entwurf der Tunnelverkleidung wichtig ist. Die Dissertation soll das Verständnis über die Faktoren verbessern, die der makroskopisch beobachteten langen Dauer des Quellprozesses zugrunde liegen. Zu diesem Zweck wird die Kinetik von Anhydritauflösung und Gipsausfällung untersucht. (Die Reaktionskinetik ist auch für den dritten Teil der Dissertation wichtig, in welchem die Wechselwirkung zwischen den chemischen Reaktionen und Transportprozessen in offenen Systemen untersucht wird.) Ein kinetisches Modell wird formuliert und anhand von vorhandenen Versuchsergebnissen für die zwei getrennten Reaktionen kalibriert. Anschliessend wird das Modell für den komplexeren Fall eines 
geschlossenen Systems mit gleichzeitiger Anhydritauflösung und Gipsausfällung verifiziert, für welchen ebenfalls Versuchsergebnisse vorliegen. Auf der Basis dieses Modells wird der Einfluss verschiedener Parameter (Anfangszusammensetzung des Gesteins, Form und die Grösse der Partikel) auf die Hydratationszeit untersucht. Die Resultate der Parameterstudien zeigen, dass die Dauer der Umwandlung von Anhydrit in Gips durch die Rate der Anhydritauflösung bestimmt wird, wenn Anhydrit in der Form von Adern (mit einer Dicke von $1 \mathrm{~mm}$ oder mehr) vorliegt und genügende Nuklei für Gipsbildung vorhanden sind. Ein interessantes Resultat ist, dass die Hydratationszeit bei diesem auflösungskontrollierten Prozess unabhängig von der anfänglichen Volumenfraktion von Anhydrit ist.

In der Natur wird oft beobachtet, dass die wachsenden Gipskritalle die Anhydritoberfläche versiegeln und die weitere Hydratation zum Stillstand bringen können. Die vorhandenen Anhydritumwandlungsmodelle berücksichtigen diesen Effekt nicht. Hier wird das gängige kinetische Modell um den Effekt der Versiegelung erweitert. Die Ergebnisse der Parameterstudien zeigen, dass die Versiegelung (abhängig von der Dicke bzw. Grösse der Anhydritader oder partikel) die zeitliche Entwicklung des Quellprozesses massgebend verlangsamen kann, und erklären die in situ Beobachtungen, dass Anhydrit in Form von dickeren Adern (von einigen $\mathrm{cm}$ ) kaum quillt.

Der dritte Teil der Dissertation handelt von der Bedeutung des advektiven und diffusiven Ionentransports. Insbesondere wird untersucht, unter welchen Bedingungen man den Ionentransport vernachlässigen darf. Diese Frage ist einerseits für den Entwurf von Laborversuchen, andererseits für die Formulierung von handhabaren kontinuumsmechanischen Modellen wichtig, die nicht mit sekundären gekoppelten Prozessen überfrachtet sind. Zur Untersuchung der Bedeutung des Ionentransports wird ein Modell formuliert, welches die chemischen Reaktionen, die Diffusion und den advektiven Ionentransport gekoppelt berücksichtigt. Da die Betrachtung der chemo-mechanischen Kopplung für die untersuchten Fragen nicht erforderlich ist, nimmt das Modell Volumenkonstanz an. Basierend auf diesem Modell werden die folgenden zwei Fragen quantitativ untersucht: (i) Wie gross ist der Einfluss der Diffusion in Oedometerversuchen? (ii) Wie gross ist der Einfluss des advektiven Ionentransports in situ? Die erste Frage ist durch die Überlegung begründet, dass die Ionendiffusion aus dem Oedometer (zum aussenliegenden distillierten Wasser) die Versuchsergebnisse verfälschen könnte, weil dann ein Teil des Anhydrits abtransportiert statt in Gips umgewandelt würde. Der Gedanke hinter der zweiten Frage ist, dass die Sickerströmung den Kalzium- und Sulfat-Gehalt in einer Region verringern und in einer anderen Region erhöhen kann. In der ersten Region würde dann Auslaugung von Anhydrit stattfinden, während sich in der zweiten Region Gips bilden könnte, selbst wenn diese Region ursprünglich vollkommen sulfatfrei wäre. Es ist daher offensichtlich, dass Ionentransport (sei es durch Advektion, sei es durch Diffusion) eine erhebliche Rolle für den Quellprozess spielen könnten. Die Rechenergebnisse zeigen allerdings, dass die Diffusion in den 
meisten Fällen irrelevant ist. Das trifft auch für den advektiven Ionentransport zu, wenn man die niedrige Geschwindigkeit der Sickerströmung in Gipskeuper berücksichtigt. Eine Auslaugung von Anhydrit (und Bildung von Gips an anderen Stellen) könnte nur im Fall einer hohen Strömungsgeschwindigkeit (höher als $10^{-5} \mathrm{~m} / \mathrm{s}$, wie z.B. in Bruchzonen) bei gleichzeitig niedriger Ionenproduktionsrate (dickere Anhydritader, kleiner Anhydritgehalt). 